\title{
Prostatın Nadir Görülen Bir Neoplazisi: Küçük Lenfositik Lenfoma
}

\section{A Rare Neoplasm of the Prostate: Small Lymphocytic Lymphoma}

\author{
Dr. Hüseyin Çelik1, Dr. Serhan Çimen1, Dr. Nusret Akpolat2 \\ 1/nönü Üniversitesi Tıp Fakültesi, Üroloji Anabilim Dalı, Malatya, Türkiye \\ 2/nönü Üniversitesi Tıp Fakültesi, Patoloji Anabilim Dalı, Malatya, Türkiye
}

\section{Özet}

Prostat lenfoması oldukça nadir görülen bir durumdur. Tüm prostat malignitelerinin \%0,09'unu oluşturur. Prastat lenfoması diğer prostat hastalıkları gibi aynı yaş grubunda ortaya çıkar ve klinik olarak birbirinden ayırmak zordur. Bu çalışmada, iki kez akut üriner retansiyona girmiş ve prostat spesifik antijen düzeyi normal olan 63 yaşındaki bir erkek hastayı sunduk. Transüretral rezeksiyon (TUR) uygulanan hastanın TUR materyalinin mikroskopik incelemesinde, difüz lenfositik infiltrasyonun olduğu ve güçlü CD20 ve CD5 pozitif ve $C D 3$ negatif boyandığı görüldü. (Üroonkoloji Bülteni 2014;13:182-183)

Anahtar Kelimeler: Küçük hücreli lenfoma, transüretral rezeksiyon, prostat lenfoması

\begin{abstract}
Summary
Prostate lymphoma is a rare condition, it accounts for $0.09 \%$ of all prostate malignancies. As other prostate diseases, prostate lymphoma occurs in the same age group and it is difficult to distinguish clinically. We report a case of 63 year-old male with acute urinary retention twice and normal serum level of prostate specific antigen. We performed transurethral resection (TUR). In the microscopic examination of the TUR material a diffuse lymphocytic infiltration which were strongly positive for CD20 and CD5 and negative for CD3. (Bulletin of Urooncology 2014;13:182-183)
\end{abstract}

Key Words: Small lymphocytic lymphoma, transurethral resection, prostate lymphoma

\section{Giriş}

Küçük lenfositik lenfoma kemik iliği, lenf nodları ve periferik kanı tutan bir B hücreli neoplazidir (1). En sık tutulan visseral organlar dalak ve karaciğerdir. Prostatın lenfoması nadir görülmek olup, tüm prostat tümörlerinin \%0,09 unu tüm Non-Hodgkin lenfomaların \%0,1 oluşturmaktadır (2). Sinsi klinik gidişli bir hastalıktır, semptomları diğer prostat hastalıklarından ayırmak zordur. Yaşlı erkeklerde daha sık görülür. Bu olgu sunumunda 63 yaşında alt üriner sistem semptomları olan prostat lenfoması olgusunun temel klinik özellikleri ve tedavisini literatür ışı̆̆ında sunduk.

\section{Olgu Sunumu}

Altmış üç yaşındaki hastanın yaklaşık dört yıldır süren alt üriner sistem semptomları mevcuttu. Özgeçmişinde KLL tanısı dışında özellik yoktu. Fizik muayenede özellik saptanmadı. Rektal muayenesinde prostat hipertrofik palpe edildi. Biyokimyasal ve hormonal laboratuvar değerleri normal sınırlarda idi. PSA değeri
2,3 ng/mL olarak ölçüldü. İdrar analizinde anormallik yoktu. Ultrasonografik muayenede her iki böbrek normal boyutlarda idi ve prostat hacmi $\sim 70$ cc saptandı. Operasyon öncesi uluslararası prostat semptom skoru (IPSS) 23 idi. Üroflowmetri parametreleri maksimal akım hızı $9 \mathrm{~mL}$, ortalama akım hızı $4 \mathrm{~mL}$ olarak ölçüldü. Değerler obstrüktif patern ile uyumlu idi. Hastaya transüretral prostat rezeksiyon (TUR-P) yapıldı. Prostatın histopatolojik ve immunohistokimyasal incelemesi sonucu patolojisi küçük lenfoisitik lenfoma olarak raporlandı (Resim 1 ve 2). Patolojik spesmenin immünohistokimyasal analizinde CD20, CD3 ve CD23 pozitişiği tespit edildi (Resim 3). Hasta KLL tedavisi açısından remisyonda olduğundan Hematoloji tarafından hastaya ek bir tedavi verilmedi ve takibine karar verildi.

\section{Tartışma}

Non-Hodgkin lenfomaların yaklaşık \%30’u ekstranodal tutulum göstermektedir. Prostat nadir de olsa bu ekstranodal tutulum içerisinde yer almaktadır. Bu hastaların yaş ortalaması genellikle 


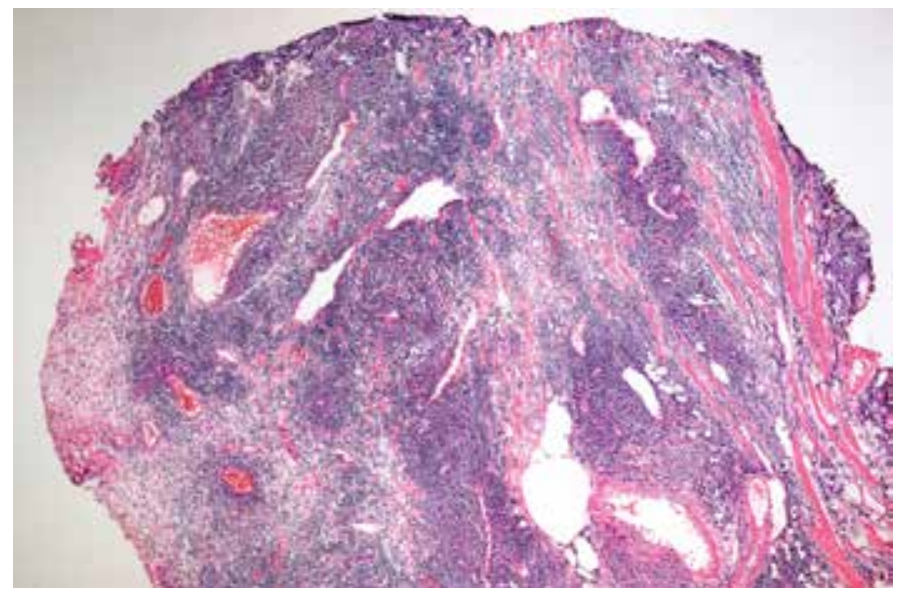

Resim 1. Difüz lenfositik infiltrasyon: Lenfoid hücreler stromal doku elemanları arasına infiltredir ( $\mathrm{HE}, \mathrm{x} 40)$

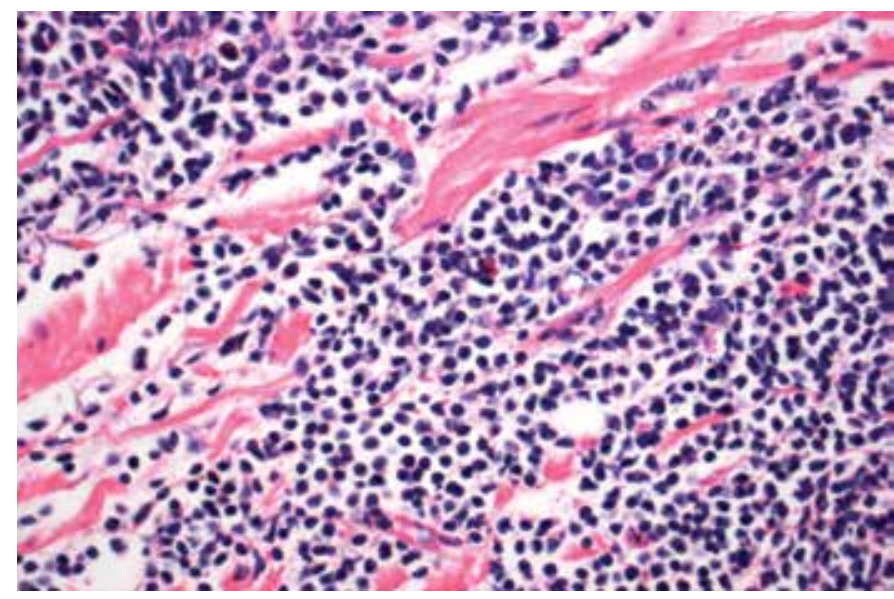

Resim 2. Infiltratif lenfoid hücreler düz kas demetleri arasında görülmektedir. Lenfoid hücreler pleomorfizm, hiperkromazi ve nükleer membran düzensizlikleri göstermektedir (HE, x200)

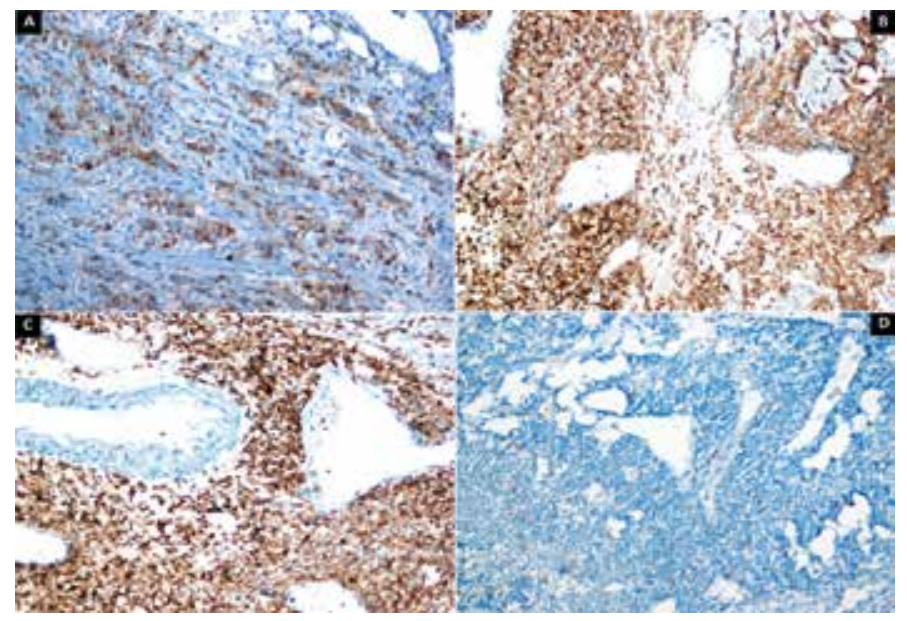

Resim 3. A: İnfiltratif lenfoid hücrelerde difüz CD20 pozitifliği, B: Solid gruplar oluşturan lenfoid hücrelerde difüz CD23 pozitifliği, C: Perivasküleryerleşen lenfoid hücrelerde Difüz CD5 pozitifliği, D: infiltratif lenfoid hücrelerde CD3 negatifliği
60 yaşından büyüktür (3). Lenfomaların prostat tutulumu genellikle alt üriner sistem semptomları ve akut üriner retansiyon şeklinde klinik vermektedir. Bu bulguya ek olarak parmakla rektal muayenede prostat büyümüş ve yumuşak kıvamda saptanabilir (4). Bizim olgumuzda da orta derece de büyümüş bir prostat parmakla rektal muayenede tespit edildi. Hastamız iki kez akut üriner retansiyonu girmişti. Prostatın lenfomasını diğer prostat hastalıklarından klinik olarak ayırt etmek zordur. Ani sıkışma hissi, sık idrara çıkma, hematüri ve akut üriner retansiyon sık klinik semptomlarıdır. Sistemik semptomları oldukça nadir görülür (5). Prostat lenfomasında serum PSA düzeyinin yüksekliği tipik bir özellik değildir (3). Bizim olgumuzda da PSA yüksekliği mevcut değildi. Bu nedenle sadece klinik verilerle prostat lenfoma tanısının konulması oldukça güçtür.

Prostat kanseri tanılı hastalarda, prostatın non-Hodgkin lenfoması insidansı, 4,319 radikal prostatektomi patolojisinin incelendiği bir seride \%0,2 (6), 1,092 olguluk diğer bir seride ise \%1,19 olduğu (7) görülmüştür. Olgumuzda hastanın yaşı ve başvuru şikayetleri prostat karsinomu semptomlarına benzer ancak TUR materyallerinin patolojik kesitleri incelendiğinde bir prostat karsinomuna rastlanmadı.

Literatürde, lösemik infiltrasyonun ancak benign prostatik hiperplazi varlığında akut üriner retansiyona yol açabileceğini bildirilmiştir (8). Hastamızın iki kez akut üriner retansiyona girmesinin bu nedenden kaynaklandığını düşünmekteyiz. Sonuç olarak, prostat lenfoması benign prostat hiperplazisi ve prostat karsinomu ile aynı yaş grubunda yer alması ve benzer semptomlar göstermesi nedeniyle klinik olarak ayrımı neredeyse imkansızdır. Bu nedenle TUR materyalinde monotipik lenfoid infiltrasyon saptanan hastalarda, beraberinde hematolenfoid bir malignite varlığında, prostatta da olası bir lenfoma infiltrasyonu olabileceği akla getirilmeli, bu olasılık klinik ve patolojik ileri incelemeler için yol gösterici olmalıdır.

Çıkar çatışması: Yazarlar bu makale ile ilgili olarak herhangi bir çıkar çatışması bildirmemişlerdir.

\section{Kaynaklar}

1. Müller-Hermelink HK, Montserrat E, Catovski D, et al. Chronic lymphocytic leukemia/small lymphocytic lymphoma. In: Jaffe ES, Harris NL, Stein H, Vardiman JW, eds. Pathology and genetics of the tumours of haematopoietic and lymphoid tissues. Lyon: IARC Press 2001;127-130.

2. Sarris A, Dimopoulos $M$, Pugh $W$, et al. Primary lymphoma of the prostate: good outcome with doxorubicin-based combined chemotherapy. J Urol 1995;153:1852-1854.

3. Bostwick DG, Iczkowski KA, Amin MB, et al. Malignant lymphoma involving the prostate:report of 62 cases. Cancer 1998;83:732-738.

4. Antunes AA, Dall'Oglio M, Srougi M. Primary lymphoma of the prostate: a rare cause of urinary obstruction. Int Braz J Urol 2004;30:410-412.

5. Tomaru $U$, Ishikura $H, K o n ~ S$, et al. Primary lymphoma of the prostate with features of low grade B lymphoma of mucosa associated lymphoid tissue: a rare cause of urinary tract obstruction. J Urol 1999; 162:496-497.

6. Eisenberger CL, Walsh PC, Eisenberger MA, et al. Incidental NonHodgkin's lymphoma in patients with localized prostate cancer. Urology 1999;53:175-179.

7. Terris MK, Hausdorff J, Freiha F. Hematolymphoid malignancies diagnosed at the time of radical prostatectomy. J Urol 1997;158:1457-1459.

8. Dajani YF, Burke M. Leukemic infiltration of the prostate. A case study and clinicopathological review. Cancer 1976;38:2442-2446. 